\title{
FORMALIZATION OF THE MARKETING CONTOUR HR-POLICIES IN THE FIELD OF AGROTOURISM IN RUSSIA AS A CONDITION FOR ITS BALANCED DEVELOPMENT
}

\author{
Galina Vukovich $^{1 *}$, Anastasiya Ostrovskaya ${ }^{1}$, Lina Zaharova ${ }^{1}$, \\ Albert Kovalenko ${ }^{1}$, Valentina Kuznecova ${ }^{2}$ \\ ${ }^{1 *}$ Kuban State University, Krasnodar, Russia; \\ ${ }^{2}$ A.I. Herzen Russian State Pedagogical University, Saint-Petersburg, Russia; \\ *Corresponding Author Galina Vukovich, e-mail: Kaf224@yandex.ru;
}

Received November 2021; Accepted December 2021; Published January 2022;

DOI: https://doi.org/10.31407/ijees12.132

\begin{abstract}
The purpose of the study is to formalize the marketing contour of the HR policy of the agrotourism sphere in Russia. The article analyzes the current state of the agrotourism market in Russia. The importance of the role of marketing communications in the development of rural tourism is considered. The main channels of marketing communications in the field of agrotourism are analyzed, the model of a complex of marketing communications focused on promoting the product of agrotourism in the Russian Federation is described. The factors hindering the development of agrotourism in Russia, as well as the system of organization of modern rural tourism are studied. The importance and significance of the process of promoting agrotouristic services is noted, a complex of modern marketing communications with agrotourists is given; Internet communications are an effective tool for promoting agrotourism objects, but for the optimal choice of the promotion concept, it is necessary to determine the portrait of a potential agrotourist. For the long-term development of agrotourism in Russia, it is necessary to develop state and regional programs to support agribusiness, increase the number of services provided, improve the territories and preserve the rich resource potential of the regions of Russia. It is noted that the contribution to the achievement of goals and the quality of services provided in the agro-tourism sector largely depends on the effectiveness of personnel selection.
\end{abstract}

Keywords: agrotourism, tourism industry, HR technologies, infrastructure, tourism management, marketing events. 